\title{
Using Host-Specificity of Cryptosporidium to Understand Contaminant Sources, Seasonality, and Human Health Risk in Three Watersheds of Differing Land-Use
}

\author{
Janis L. Thomas ${ }^{1}$, Katarina D. M. Pintar ${ }^{2}$, Peter M. Wallis ${ }^{3}$, Norman F. Neumann ${ }^{4}$ \\ ${ }^{1}$ Environmental Monitoring and Reporting Branch, Ontario Ministry of the Environment and Climate Change, \\ Toronto, Canada \\ ${ }^{2}$ Centre for Food-Borne, Environmental and Zoonotic Infectious Diseases (CFEZID), Public Health Agency of \\ Canada, Ottawa, Canada \\ ${ }^{3}$ Hyperion Research Ltd., Medicine Hat, Canada \\ ${ }^{4}$ School of Public Health, University of Alberta, Edmonton, Canada \\ Email: Janis.Thomas@ontario.ca
}

Received 18 January 2016; accepted 23 February 2016; published 26 February 2016

Copyright (C) 2016 by authors and Scientific Research Publishing Inc.

This work is licensed under the Creative Commons Attribution International License (CC BY).

http://creativecommons.org/licenses/by/4.0/

(c) (i) Open Access

\section{Abstract}

Three tributaries of the Grand River watershed (Ontario, Canada), each representing different watershed types (urban, agricultural/rural, and mixed land-use) were examined to understand the spatial, temporal, and host-source distribution of the waterborne pathogen, Cryptosporidium. Cryptosporidium was frequently found throughout the study $(73 \%, 65 / 89)$ with occurrence and concentrations observed to be similar among the varying watershed types. However, applying advanced genotyping techniques, marked differences in dominant host sources could be observed in each watershed. The agricultural/rural and mixed land-use watersheds were dominated by genotypes typically associated with cattle (i.e., C. andersoni), while the urban watershed had the highest diversity of Cryptosporidium genotypes with a variety of wildlife as the common source of contamination (e.g., muskrat and cervine genotypes). A similar seasonal trend observed in the urban, agricultural, and mixed land-use watershed suggests that factors beyond specific land use activities (e.g. autumn manure spreading) may influence the timing and concentration of Cryptosporidium in these streams. Corresponding genotyping results provided additional insight into source inputs during these seasonal peaks, indicating that wildlife may be important seasonal contributors to Cryptosporidium contamination in these streams. Despite the abundance of Cryptosporidium in these watersheds, most of the genotypes observed were of limited human health importance. This study provides evidence regarding the significance of including genotyping results into studies examining waterborne Cryptosporidium. Using this technique can provide a greater un- 
derstanding of the risk to the population using water sources, as well as provide insight into the probable sources and timing of contamination. This ancillary information can contribute to implementation of targeted management strategies to further protect sources of drinking water and recreation areas.

\title{
Keywords
}

\author{
Cryptosporidium, Genotyping, Source Tracking, Health Risk, Water Contamination
}

\section{Introduction}

Cryptosporidium is a well-recognized waterborne pathogen that has been implicated in drinking water and recreational water outbreaks in North America and around the world [1]-[4]. As part of its life cycle, Cryptosporidium produces an environmentally robust oocyst stage that is shed in very large numbers in the feces of infected animals and humans, thereby increasing environmental contamination. Agricultural animals, particularly cattle, are well recognized as a source of Cryptosporidium [4]-[7]. However, a wide range of host animals can be infected and excrete Cryptosporidium in their feces, including domestic animals, various wildlife, and humans [6] [8]-[11]. Given the host range of Cryptosporidium, many fecal sources can be a source of contamination to water, including sewage treatment discharges, run-off from cropland following manure application, and direct access of domestic and wild animals to water sources.

Many Cryptosporidium species are host-adapted, meaning that they specifically infect certain types of animals over others. For example, C. andersoni is commonly associated with post-weaned cattle and C. baileyi predominantly infects birds [7] [11]. Two species of Cryptosporidium are primarily responsible for human infections: C. hominis and C. parvum. C. hominis is host-adapted and found almost exclusively in humans [11]. C. parvum is less host-adapted and can infect a range of animals including humans and cattle [12]-[14].

Routine detection and enumeration of Cryptosporidium from water, particularly for regulatory compliance, are conducted microscopically using standard methods such as US EPA Method 1622 and 1623 [15] [16]. These methods allow for the detection and enumeration of total Cryptosporidium oocysts in a water sample; however, they do not differentiate between specific species/genotypes. Over the past decade, some researchers have applied advanced molecular methodologies to examine the genotypes in water samples. Distinguishing between genotypes can provide a refined estimation of the potential human health risk that this contamination poses to the public. In addition, due to the host-adapted nature of many Cryptosporidium species this additional information can provide a better understanding of the predominant sources of this contamination in a watershed, which can assist in source tracking this type of contamination and provide additional insight into future management and protection strategies for specific water sources.

The objectives of this study were to compare the prevalence of Cryptosporidium in three watersheds impacted by differing land-uses (agricultural/rural, mixed land-use, and urban-dominated watersheds) and apply advanced genotyping techniques to: 1) understand the dominant host sources of this pathogen in each watershed and among seasons; and, 2) determine the prevalence of species that may pose a risk to human health.

\section{Methods}

\subsection{Sampling Sites}

Three sub-watersheds within the Grand River Watershed (Ontario, Canada) with varying dominant land-uses were chosen for sampling (Figure 1). Schneider Creek is a highly urban watershed with dense roads and residential/industrial areas. No point sources of contamination exist on this stream, such as sewage treatment discharges, however; this stream is impacted by storm water discharges throughout the year. The sample location on the Nith River is in the headwaters of this sub-watershed which is agriculturally-dominated. Canagagigue Creek is a mixed land-use sub-watershed, with intensive agriculture and a small urban area with a sewage treatment discharge outfall located upstream of the sample collection point (see Table 1). 


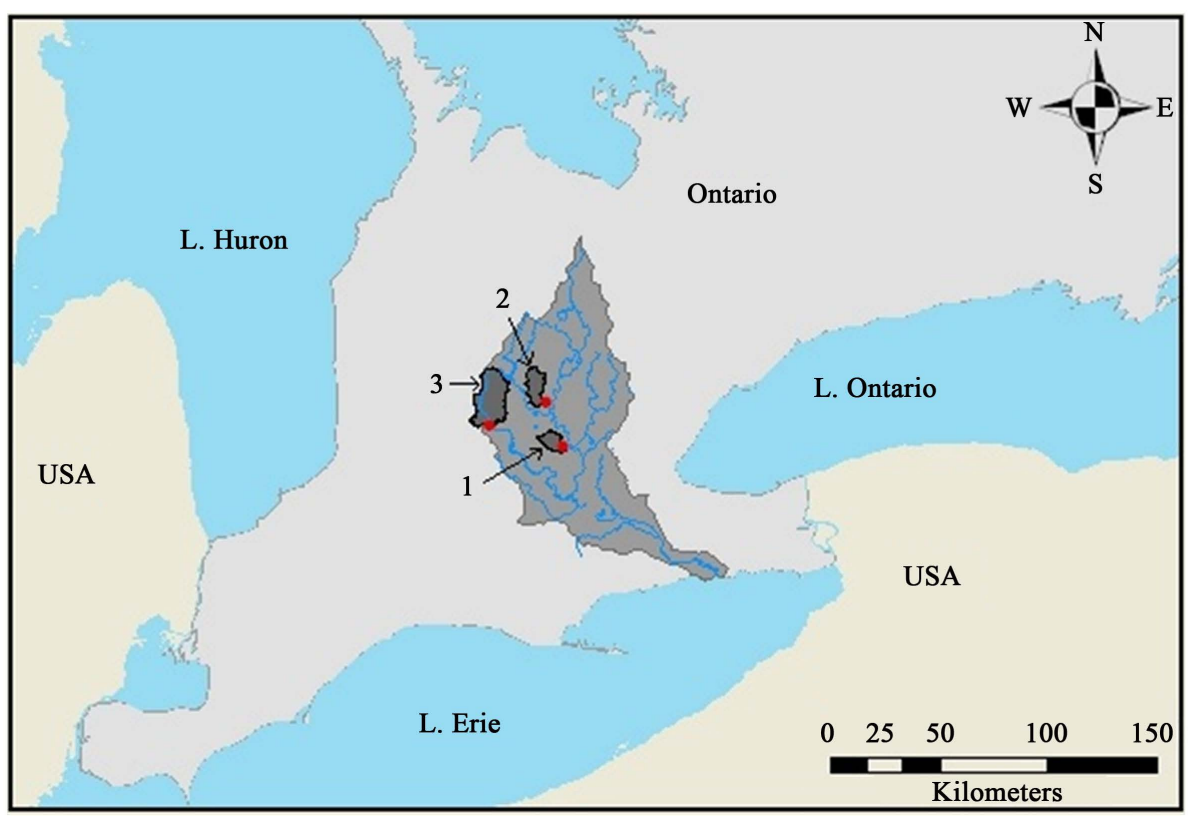

Figure 1. Grand River watershed (in light grey) Southwestern Ontario, Canada that discharges into Lake Erie and three subwatersheds (dark grey) and sample locations included in this study; 1) Schneider Creek; 2) Canagagigue Creek; and 3) Nith River.

Table 1. Watershed characterization and Cryptosporidium oocysts occurrence in three tributaries of the Grand River watershed.

\begin{tabular}{|c|c|c|c|c|c|c|c|}
\hline \multirow[b]{2}{*}{ Stream name } & \multicolumn{3}{|c|}{ Watershed information } & \multirow{2}{*}{$\begin{array}{l}\text { Number of } \\
\text { samples } \\
\text { taken }\end{array}$} & \multicolumn{3}{|c|}{ Cryptosporidium oocysts } \\
\hline & $\begin{array}{l}\text { Watershed } \\
\text { area }\left(\mathrm{km}^{2}\right)\end{array}$ & $\begin{array}{c}\% \\
\text { Agriculture }^{\mathrm{a}}\end{array}$ & $\begin{array}{c}\% \\
\text { Urban }^{\mathrm{a}}\end{array}$ & & $\begin{array}{c}\text { Number of. } \\
\text { positive samples }\end{array}$ & Occurrence (\%) & $\begin{array}{l}\text { Concentration. range } \\
\text { (above } \mathrm{DL}^{\mathrm{C}} \text { ) per } 100 \mathrm{~L}\end{array}$ \\
\hline Schneider Creek & 71 & 33 & 57 & 32 & 19 & 59.4 & $1.6-80.4$ \\
\hline Canagagigue Creek & 111 & 87 & $4^{\mathrm{b}}$ & 38 & 32 & 84.2 & $1.0-282.8$ \\
\hline Nith River & 313 & 91 & 0 & 19 & 14 & 73.7 & $1.0-500.0$ \\
\hline
\end{tabular}

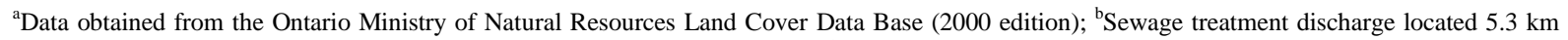
upstream of site, facility provides tertiary treatment including UV disinfection; ${ }^{\mathrm{C}} \mathrm{DL}=$ theoretical detection limit (1.0 to 45.5 oocystsper $\left.100 \mathrm{~L}\right)$.

\subsection{Sample Collection and Water Quality Analysis}

Samples were collected between September 2007 and August 2009. Samples were taken once to several times per month so as to obtain samples representing a range of hydrological conditions including base-flow and storm-flow (rain events and snow melt).

Surface water samples were filtered on-site, up to a maximum of 100 litres (L), using IDEXX filters (comprised of compressed foam discs to capture particulate) and filtration housings (IDEXX Laboratories Ltd., Markham, ON). Following filtration, each filter was placed in a sterile whirl pack bag and shipped on ice overnight to the laboratory (Hyperion Research Ltd., Medicine Hat, AB) for analysis using US EPA method 1623 [16] and processed within 72 hours of collection. US EPA 1623 method involves the elution and concentration of debris/trapped material from each filter. The Cryptosporidium oocysts are separated from this debris using magnetic beads coated with antibodies specific for the antigen proteins on the outside wall of oocysts (GCCombo magnetic beads, Invitrogen, Oslo, Norway). Once separated and washed, the cells were treated with monoclonal antibodies with CY3 fluorochrome conjugates (Waterborne Inc, New Orleans, LA) to cause oocysts to fluoresce under ultra-violet (UV) light during microscopic examination (Zeiss Axioskop, Carl Zeiss Canada Ltd, Canada). Cells were also counter-stained with 4',6-diamidino-2-phenylindole (DAPI) and examined under differential interference contrast (DIC) microscopy for confirmation. During this study, recovery of spiked sam- 
ples was within the range specified by US EPA Method 1623 [16], with recoveries reported at 38.5\% (Residual Standard Deviation; RSD, 30.3) for Cryptosporidium oocysts.

In preparation for genotyping, the material on each microscope slide, was prepared and subject to cell lysis and DNA extractions, as described by [17]. This method involves the lysis of cells following several freeze/thaw cycles $\left(2\right.$ minutes (min.) in liquid nitrogen and $5 \mathrm{~min}$. at $65^{\circ} \mathrm{C}$ ) followed by DNA extraction (DNeasy Kit, Qiagen, Mississauga, ON).

The extracted DNA was sent to the Alberta Provincial Health Laboratory (Calgary, AB) where repetitive nested-PCR(polymerase chain reaction), restriction fragment length polymorphism (RFLP) analysis, and sequencing were performed as described in [17] [18]. A total of five replicate PCR reactions were performed per sample to determine if more than one species were present in a sample. PCR products were sequenced (Sun Center of Excellence for Visual Genomics, University of Calgary, Calgary, AB) and results were compared to known Cryptosporidium sequences in a reference database maintained at the University of Calgary prior to assigning a genotype name to a specific sample.

\subsection{Data Analysis and Statistical Testing}

Non-parametric statistical methods were used as the microbiological data were not-normally distributed. All data were analyzed using Excel (Microsoft Office) and SigmaPlot (version 12.1). Fisher's exact and Chi square tests were applied to test for significant spatial differences $(P<0.05)$ in occurrence of Cryptosporidium oocystsamong streams and between seasons (Winter: Dec-Feb, Spring: Mar-May, Summer: Jun-Aug, and Fall: SepNov). Kruskal-Wallis testing (nonparametric ANOVA on ranks) was conducted to examine differences ( $P<$ 0.05 ) in densities among streams and seasons, with significant differences further identified using Dunn's multiple comparison test, which is an appropriate nonparametric pairwise multiple comparison procedure when a Kruskal-Wallis test is rejected.

Cryptosporidium were considered present if the value reported was above the method detection limit (1.0 to 45.5 oocysts per $100 \mathrm{~L}$ ). In a few instances $(\mathrm{n}=8$ ), samples were also considered positive for Cryptosporidium when detected through PCR (following genotyping analysis), but were below the detection limit following microscopic detection. These PCR positive, microscopic negative results were only used for occurrence analysis.

\section{Results}

Cryptosporidium oocysts were detected in 73\% (65/89) of the water samples. Fifty-seven samples were positive following microscopic analysis, with 8 additional samples positive following molecular analysis. The proportion of samples positive for Cryptosporidium in each stream is shown in Table 1. Significant differences in Cryptosporidium oocysts occurrences were not detected among streams $(P=0.7)$.

The median concentration of Cryptosporidium was 3.3 oocysts $/ 100 \mathrm{~L}$, with values ranging from less than the method detection limit to 500 oocysts/100 L. Differences were not observed $(P=0.25)$ in the median concentration of Cryptosporidium among streams. A wide range of Cryptosporidium concentrations were observed in all streams, with the greatest variability in the Nith River (Figure 2) and the lowest in Schneider Creek.

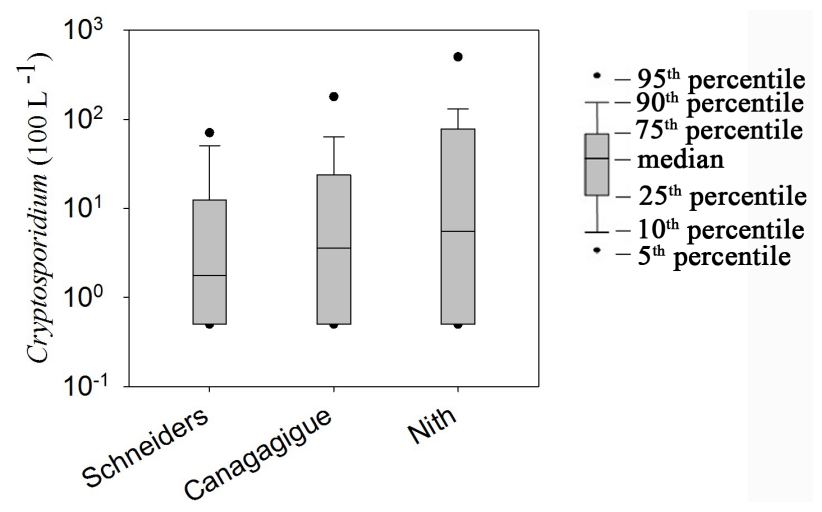

Figure 2. Cryptosporidium concentrations in three streams in the Grand River watershed. 
Significant differences $(P<0.05)$ in the occurrence of Cryptosporidium were observed with season. Overall, fall months (September to November) revealed the greatest frequency of Cryptosporidium occurrence (19/20) which was significantly different $(P<0.001)$ from the levels observed in both winter $(13 / 24)$ and spring $(12 / 28)$. Differences $(P>0.05)$ were not observed between occurrences in the summer $(12 / 17)$ and the other seasons. This trend was apparent in all three streams, with the fall months showing the greatest occurrence of Cryptosporidium. In many instances, the summer months showed high occurrence levels as well (Figure 3).

Similar to occurrence levels, differences in median concentrations for Cryptosporidium were observed among seasons $(P<0.001)$. In general, higher median values were observed in the summer and fall for Cryptosporidium, compared to the winter and spring (Figure 4). The highest median concentration was observed in the summer, which was significantly different to the median concentrations observed in the winter and spring, but not the fall, following a pairwise multiple comparisons test. Spring revealed the greatest portion of non-detectable samples. Although the lowest median concentration for Cryptosporidium occurred in the spring months, this season showed great variability and the highest reported level for this parasite for the entire study period at 500 oocysts per $100 \mathrm{~L}$.

A total of 26 water samples generated positive genotyping results. Of these samples, 9 distinct Cryptosporidium genotypes were found (Table 2). The most common species detected was $C$. andersoni, which was found in 19 water samples. In most instances, only one genotype was detected, however, 19\% (5/26) of the samples revealed more than one different genotype in a single sample.

Samples from Schneider Creek showed the most diverse range of genotypes (total of 8 different genotypes), followed by Canagagigue Creek (4 different genotypes). Samples from the Nith River only revealed one genotype, C. andersoni, throughout the study period (Table 2). Although positive microscopic detection of Cryptosporidium oocysts occurred throughout all of these seasons (Figure 3), positive genotype results (through molecular analysis) were more commonly reported in samples taken in the summer and fall months (Table 2).

Table 2. Cryptosporidium genotypes observed in each watershed and with season, associated health risk, and sources.

\begin{tabular}{|c|c|c|c|c|c|c|c|c|c|}
\hline \multirow{2}{*}{$\begin{array}{l}\text { Stream } \\
\text { name }\end{array}$} & \multirow{2}{*}{$\begin{array}{l}\text { Genotypes } \\
\text { detected }\end{array}$} & \multirow{2}{*}{$\begin{array}{l}\text { Human } \\
\text { health risk } \\
\text { class }^{\mathrm{b}}\end{array}$} & \multirow{2}{*}{$\begin{array}{c}\text { Common } \\
\text { host-sources }^{c}\end{array}$} & \multirow{2}{*}{$\begin{array}{c}\text { Proportion } \\
\text { of } \\
\text { genotypes } \\
\text { obtained } \\
\text { in stream }\end{array}$} & \multirow{2}{*}{$\begin{array}{l}\text { No. water } \\
\text { samples } \\
\text { positive for } \\
\text { genotype }\end{array}$} & \multicolumn{4}{|c|}{ Season genotype detected } \\
\hline & & & & & & Winter & Spring & Summer & Fall \\
\hline Nith River & C. andersoni & Low & $\begin{array}{l}\text { Ruminants (predominantly } \\
\text { adult cattle, }>3 \text { months) }\end{array}$ & $100 \%$ & 3 & & & & \\
\hline \multirow{4}{*}{$\begin{array}{l}\text { Canagagigue } \\
\text { Creek }\end{array}$} & C. andersoni & Low & $\begin{array}{l}\text { Ruminants (predominantly } \\
\text { adult cattle, >3 months) }\end{array}$ & $80 \%$ & 16 & & & & \\
\hline & W12 genotype & None & Unknown-likely wildlife & $10 \%$ & 2 & & & & \\
\hline & C. baileyi & None & Avian & $5 \%$ & 1 & & & & \\
\hline & W25 genotype & None & Unknown-likely wildlife & $5 \%$ & 1 & & & & \\
\hline \multirow{8}{*}{ Schneider Creek } & C. baileyi & None & Avian & $22 \%$ & 2 & & & & \\
\hline & C. parvum & High & $\begin{array}{l}\text { Humans, ruminants } \\
\text { (in particular pre-weaned } \\
\text { calves }<3 \text { months) }\end{array}$ & $11 \%$ & 1 & & & & \\
\hline & $\begin{array}{l}\text { Cervine } \\
\text { genotype II }\end{array}$ & Medium & Deer, sheep & $11 \%$ & 1 & & & & \\
\hline & $\begin{array}{l}\text { Deer mouse } \\
\text { genotype III }\end{array}$ & None & Deer mouse & $11 \%$ & 1 & & & & \\
\hline & $\begin{array}{l}\text { Muskrat } \\
\text { genotype }\end{array}$ & None & Muskrat, vole & $11 \%$ & 1 & & & & \\
\hline & $\begin{array}{l}\text { Skunk } \\
\text { genotype }\end{array}$ & Low & Skunk, raccoon & $11 \%$ & 1 & & & & \\
\hline & W12 genotype & None & Unknown-likely wildlife & $11 \%$ & 1 & & & & \\
\hline & W25 genotype & None & Unknown-likely wildlife & $11 \%$ & 1 & & & & \\
\hline
\end{tabular}

${ }^{\mathrm{a}}$ C. ubiquitum; ${ }^{\mathrm{b}}$ Reference [19]; ${ }^{\mathrm{c}}$ References [7] [11] [19] [20]. 


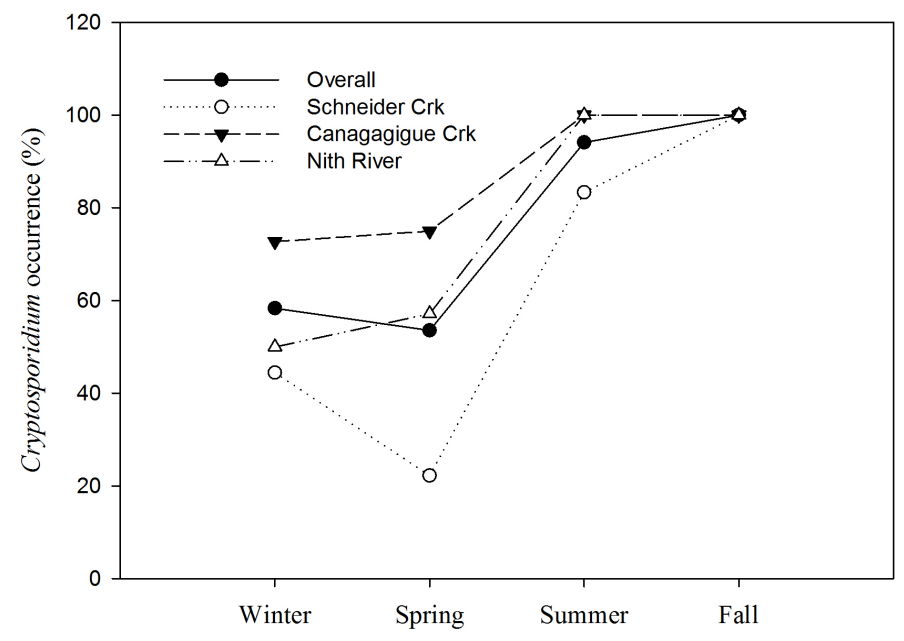

Figure 3. Seasonal trends in the occurrence of Cryptosporidium overall (data for all streams combined) and within each stream studied. Connecting lines shown for clarity.

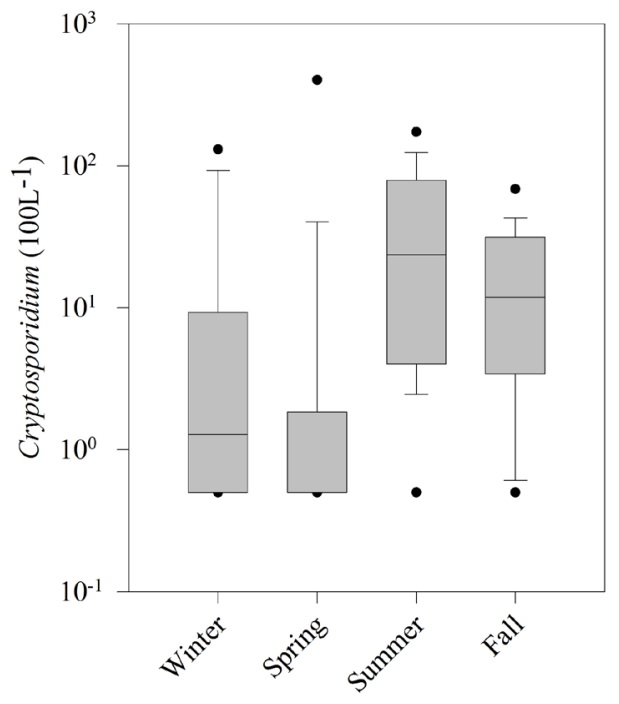

Season

Figure 4. Median and range of Cryptosporidium concentrations throughout all seasons.

\section{Discussion}

This study examined the spatial and temporal distribution of Cryptosporidium within three tributaries of the Grand River watershed, with the objective to apply advanced genetic techniques to identify predominant host sources of Cryptosporidium contamination within each stream and among seasons, as well as to determine the prevalence of genotypes that may pose a risk to human health.

Overall, there was frequent detection of Cryptosporidium (73\%) throughout this two year study. Similar levels and concentrations of Cryptosporidium were observed among the urban, agricultural, and mixed land-use watersheds, however, genotyping results revealed discernible differences in host sources among watersheds. $C$. andersoni was the most frequently detected genotype in this study, where it was the dominant genotype observed in the agricultural watershed (Nith River) and in the mixed land-use watershed (Canagagigue Creek), which is reflective of the livestock intensity and production of manure in these two streams. This genotype is commonly associated with adult cattle [6] [7] and is frequently reported in watersheds when agricultural activi- 
ties are occurring on the landscape [18] [19] [21] [22]. Despite the dominance of this genotype in this study, C. andersoni is considered low risk to human health [12].

In contrast to the Nith River and Canagagigue Creek, no C. andersoni was observed in the urban watershed (Schneider Creek), which is reflective of the limited occurrence of agricultural activities on the landscape. Overall, the urban watershed had the highest diversity of Cryptosporidium genotypes with a variety of wildlife as the common source of contamination (e.g., muskrat, skunk, and cervine genotypes [20]). A similar finding was reported by [23] who observed a large diversity of wildlife-associated Cryptosporidium species in urban storm water samples in three New York watersheds.

Samples from Canagagigue Creek also showed the occurrence of several wildlife-associated genotypes (e.g., C. baileyi, and W12 and W25 genotypes), demonstrating that wildlife plays a role in the fecal contamination in this watershed in addition to livestock. Recently [19] showed the utility of using genotyping techniques to identify that wildlife, not just livestock, are important contributors to Cryptosporidium contamination in mixed land-use watersheds.

In Canagagigue and Schneider Creeks a single wildlife species did not predominate and the diversity of genotypes obtained reflects the range of wildlife that can be a source of contamination to these watersheds. Wildlife have been shown to carry diverse Cryptosporidium species, although the prevalence of carriage is largely unknown and tends to vary by animal-type [8] [9] [20]. Following the analysis of scat samples from small wild animals, [9] reported a range of Cryptosporidium prevalence rates with the lowest detection in beavers $(0 \%)$ and the highest detection in muskrats (12\%), with few species of human health significance observed. A study by [20] reported a 20.5\% prevalence rate of Cryptosporidium in various wildlife species with a higher prevalence in small mammals (including deer mice and squirrels), lower carriage in wild birds, and no detection in fish.

Schneider Creek was the only stream where genotypes that infect humans were found, including the detection of $C$. parvum (high risk to human health) and the cervine genotype (also called C. ubiquitum), which can be considered a moderate risk to human health. The cervine genotype has been detected in a range of wildlife [20]. Although most often associated with infections in humans and in pre-weaned cattle, C. parvum is considered to have a broad host range. Wildlife such as squirrels and Canada geese have been shown to carry this species at a low frequency, although its prevalence in many wildlife animals remains elusive [8] [20]. The lack of host specificity for this species indicates that its occurrence in the urban stream cannot be associated with any particular animal source in this tributary. It does, however, indicate that there may be an elevated risk to people that might be exposed to this urban water source (i.e., accidental ingestion while wading/playing in the water) compared to the other streams included in this study.

Despite the fact that there was a sewage treatment plant (STP) effluent discharge upstream of the sample location on Canagagigue Creek, no strains that are commonly associated with human infections (C. parvum and C. hominis) were detected. This finding indicates that during the time of this study the sewage treatment outfall was contributing minimal Cryptosporidium contamination to the stream in comparison to livestock activities in the area, which is likely related to the treatments process, including UV disinfection, at this STP.

Peaks in Cryptosporidium abundance and densities were observed in the summer and fall in this study. Similar trends have been reported in other watersheds with increases in the fall months generally attributed to agricultural inputs [19] [24], although seasonal trends are not always consistently observed among studies e.g., [22].

Seasonal trends in Cryptosporidium abundance in surface water have been suggested to correspond to changes in the source of contamination e.g., [19]. These seasonal differences can include changes in land-use practices such as seasonal manure-application to fields and potential seasonal variations in host animal shedding intensity. In addition, changes in hydrologic events, including increased precipitation during certain seasons, may lead to enhanced transport of Cryptosporidium from land-based fecal material to a water course [18] [19] [24] [25].

While seasonal differences in agricultural activities may account for some portion of the seasonal differences in oocysts abundance in the agriculturally-dominated watersheds, this does not explain why similar seasonal trends were observed in the urban watershed where agricultural activities are minimal. This observation suggests that factors beyond specific land use activities (e.g. autumn manure spreading) may influence the timing and concentration of Cryptosporidium in these streams. The genotyping results provided additional insight into the host animals responsible for peak contamination levels during the summer and fall months. In the Nith River and Canagagigue Creek, cattle-associated $C$. andersoni were observed in many different seasons. However, the 
genotyping data revealed a greater detection of wildlife-associated species in the summer and fall seasons. These data suggest that seasonal peaks in occurrence and abundance of Cryptosporidium may be related to increased inputs from wildlife.

These seasonal trends in wildlife-associated strains may be related to changes in infections/excretion of Cryptosporidium in wildlife during these seasons, although this remains unknown. The influx of migratory animals, in particular birds, during these seasons may also account for some portion of the observed seasonal trend. For example, the summer and fall were the only seasons where $C$. baileyi was detected, which is considered to be of avian origin [11]. A similar suggestion was made by [24] while examining un-impacted streams in Texas. Although no genotyping data were reported, they suggested that seasonal Cryptosporidium peaks observed in a stream located in a wildlife refuge may be the result of migratory birds that frequent this area during this timeframe. Reference [26] reported a similar finding in two agricultural streams in Massachusetts where they observed birds as a source of oocysts and reported higher occurrence in the summer and fall months that corresponded to an influx of migratory bird in these areas.

Unfortunately, the genotyping method used in this study is not a quantitative evaluation; therefore changes in the density of wildlife-associated species with season cannot be made. However, this genotyping method tends to identify the predominant species in a water sample [27] and therefore suggests that wildlife-associated species are in high abundance during the summer and fall months.

These results imply that agricultural-activities may not be the only factor contributing impacts throughout the year. Few studies have included genotyping analysis along with seasonal investigations of Cryptosporidium occurrence in water [19]. Data of this type may be important for understanding which host animals are major seasonal contributors to contamination in watersheds and could lead to targeted strategies for mitigation in the future.

In addition to understanding the sources of contamination, applying advanced molecular genotyping analysis can provide additional insight into the health importance of Cryptosporidium species present in the water. This information can provide a more accurate assessment about the potential health risks associated with contamination in a specific watershed. Based on microscopic results alone, which is the method commonly used for regulatory compliance in various countries, the risk to human health could be overestimated. With the addition of genotyping analysis, few Cryptosporidium species of human health significance were observed in the study watersheds $(<10 \%$ of the genotypes). Two species are predominantly responsible for infections in humans: $C$. hominis and C. parvum [12]. C. parvum, a species commonly associated with infections in humans and young cattle [12]-[14], was rarely observed in this study. C. hominis, which is only associated with human disease, was never detected in the three streams over the study period, although it has been detected in the Grand River watershed previously [6] [22]. When genotyping data are considered, there may be a reduced risk to the population using these waters as a source of drinking water and for recreation.

As more studies include genotyping techniques, there is a greater indication that genotypes of significant risk to the population are not as predominant as once assumed. Microscopic detection alone, without applying advanced genotyping analysis, could result in an over estimation of the health risk.

Although the genotypes observed in this stream are considered of limited human health importance, fecal contamination from both livestock and wildlife can carry other pathogens that have the ability to infect humans, including bacteria such as Campylobacter, Salmonella and pathogenic E. coli [6] [28]. As well, there is a possibility that pathogenic strains of Cryptosporidium could be undetected if not the predominant genotype in these streams. While the genotyping method used in this study is suitable for detecting multiple species of Cryptosporidium in a sample, as was observed in this study, it has been shown to favour the detection of the predominant species in a sample [27].

\section{Conclusion}

To better manage and protect sources of drinking water and recreation areas, an understanding of the occurrence and probable sources of pathogen contamination is needed. This study demonstrated that Cryptosporidium was ubiquitous in watersheds that were impacted by a range of land-uses, including urban, agricultural, and mixed land uses. Occurrence data alone could not determine the potential sources of Cryptosporidium; however, applying advanced molecular genotyping analysis proved to be a useful tool for understanding the dominant sources of Cryptosporidium in each watershed, as well as provided greater insight into seasonal contaminant sources. Knowledge of the various genotypes can also provide additional insight into the health importance of 
Cryptosporidium present in the water, therefore providing a more accurate assessment about the potential health risks associated with this contamination. Despite the abundance of Cryptosporidium in these watersheds, most of the genotypes observed were of limited human health importance. This study provides evidence regarding the significance of including genotyping results into studies examining waterborne Cryptosporidium. Collecting this type of information can lead to targeted management strategies to further protect sources of drinking water and recreation areas.

\section{Acknowledgements}

Special thanks to staff at the Ontario Ministry of the Environment and Climate Change that were involved with sample collection, particularly Dave Supper and Beth Gilbert, and Georgina Kaltenecker for GIS support.

\section{References}

[1] Mackenzie, W.R., Schell, W.L., Blair, K.A., Addiss, D.G., Peterson, D.E., Hoxie, N.J., Kazmierczak, J.J. and Davis, J.P. (1995) Massive Outbreak of Waterborne Cryptosporidium Infection in Milwaukee, Wisconsin: Recurrence of Illness and Risk of Secondary Transmission. Clinical Infectious Diseases, 21, 57-62. http://dx.doi.org/10.1093/clinids/21.1.57

[2] Schuster, C.J., Ellis, A.G., Robertson, W.J., Charron, D.F., Aramini, J.J., Marshall, B.J. and Medeiros, D.T. (2005) Infectious Disease Outbreaks Related to Drinking Water in Canada, 1974-2001. Canadian Journal of Public Health, 96, 254-258.

[3] Center for Disease Control and Prevention (CDC) (2008) Surveillance for Waterborne Disease and Outbreaks Associated with Drinking Water and Water Not Intended for Drinking-United States, 2005-2006. MMWR, 57, 39-69.

[4] World Health Organisation (WHO) (2011) Guidelines for Drinking-Water Quality. 4th Edition, WHO Press, Switzerland.

[5] Olson, M.E., Thorlakson, C.L., Deselliers, L., Morck, D.W. and McAllister, T.A. (1997) Giardia and Cryptosporidiumin Canadian Farm Animals. Veterinary Parasitology, 68, 375-381. http://dx.doi.org/10.1016/S0304-4017(96)01072-2

[6] Government of Canada (2012) Canadian National Enteric Pathogen Surveillance System (C-EnterNet) Annual Report-2009. Guelph, ON. Public Health Agency of Canada.

[7] Fayer, R., Santin, M. and Dargatz, D. (2010) Species of Cryptosporidium Detected in Weaned Cattle on Cow-Calf Operations in the United States. Veterinary Parasitology, 170, 187-192. http://dx.doi.org/10.1016/j.vetpar.2010.02.040

[8] Zhou, L., Kassa, H., Tischler, M.L. and Xiao, L. (2004) Host-Adapted Cryptosporidium spp. in Canada Geese (Branta canadensis). Applied and Environmental Microbiology, 70, 4211-4215. http://dx.doi.org/10.1128/AEM.70.7.4211-4215.2004

[9] Zhou, L., Fayer, R., Trout, J.M., Ryan, U.M., Schaefer III, F.W. and Xiao, L. (2004) Genotypes of Cryptosporidium Species Infecting Fur-Bearing Mammals Differ from Those of Species Infecting Humans. Applied and Environmental Microbiology, 70, 7574-7577. http://dx.doi.org/10.1128/AEM.70.12.7574-7577.2004

[10] Ferguson, C.M., Charles, K. and Deere, D.A. (2008) Quantification of Microbial Sources in Drinking-Water Catchments. Critical Reviews Environmental Science and Technology, 39, 1-40. http://dx.doi.org/10.1080/10643380701413294

[11] Fayer, R. (2010) Taxonomy and Species Delimitation in Cryptosporidium. Experimental Parasitology, 124, 90-97. http://dx.doi.org/10.1016/j.exppara.2009.03.005

[12] Leoni, F., Amar, C., Nichols, G., Pedraza-Díaz, S. and McLauchlin, J. (2006) Genetic Analysis of Cryptosporidium from 2414 Humans with Diarrhoea in England between 1985 and 2000. Journal of Medical Microbiology, 55, 703-707. http://dx.doi.org/10.1099/jmm.0.46251-0

[13] Trotz-Williams, L.A., Martin, D.S., Gatei, W., Cama, V., Peregrine, A.S., Martin, S.W., Nydam, D.V., Jamieson, F. and Xiao, L. (2006) Genotype and Subtype Analyses of Cryptosporidium Isolates from Dairy Calves and Humans in Ontario. Parasitology Research, 99, 346-352. http://dx.doi.org/10.1007/s00436-006-0157-4

[14] Santin, M., Trout, J.M. and Fayer, R. (2008) A Longitudinal Study of Cryptosporidiosis in Dairy Cattle from Birth to Two Years of Age. Veterinary Parasitology, 155, 15-23. http://dx.doi.org/10.1016/j.vetpar.2008.04.018

[15] United States Environmental Protection Agency (USEPA) (2005) Method 1622: Cryptosporidium in Water by Filtration/IMS/FA. Office of Water. EPA 815-R-05-001. http://nepis.epa.gov/Exe/ZyPDF.cgi/P100995N.PDF?Dockey=P100995N.PDF

[16] United States Environmental Protection Agency (USEPA) (2005) Method 1623: Cryptosporidium and Giardia in Wa- 
ter by Filtration/IMS/FA. Office of Water. EPA 815-R-05-002.

http://www.epa.gov/sites/production/files/2015-07/documents/epa-1623.pdf

[17] Ruecker, N.J., Bounsombath, N., Wallis, P., Ong, S.S.L., Isaac-Renton, J.L. and Neumann, N.F. (2005) Molecular Forensic Profiling of Cryptosporidium Species and Genotypes in Raw Water. Applied and Environmental Microbiology, 71, 8991-8994. http://dx.doi.org/10.1128/AEM.71.12.8991-8994.2005

[18] Ruecker, N.J., Braithwaite, S.L., Topp, E., Edge, T., Lapen, D.R., Wilkes, G., Robertson, W., Medeiros, D., Sensen, C.W. and Neumann, N.F. (2007) Tracking Host Sources of Cryptosporidium spp. in Raw Water for Improved Health Risk Assessment. Applied and Environmental Microbiology, 73, 3945-3957. http://dx.doi.org/10.1128/AEM.02788-06

[19] Wilkes, G., Ruecker, N.J., Neumann, N.F., Gannon, V.P.J., Jokinen, C., Sunohara, M., Topp, E., Pintar, K.D.M., Edge, T.A. and Lapen, D.R. (2013) Spatiotemporal Analysis of Cryptosporidium Species/Genotypes and Relationships with Other Zoonotic Pathogens in Surface Water from Mixed-Use Watersheds. Applied and Environmental Microbiology, 79, 434-448. http://dx.doi.org/10.1128/AEM.01924-12

[20] Feng, Y., Alderisio, K.A., Yang, W., Blancero, L.A., Kuhne, W.G., Nadareski, C.A., Reid, M. and Xiao, L. (2007) Cryptosporidium Genotypes in Wildlife from a New York Watershed. Applied and Environmental Microbiology, 73, 6475-6483. http://dx.doi.org/10.1128/AEM.01034-07

[21] Yang, W., Chen, P., Villegas, E.N., Landy, R.B., Kanetsky, C., Cama, V., Dearen, T., Schultz, C.L., Orndorff, K.G., Prelewicz, G.J., Brown, M.H., Young, K. and Xiao, L. (2008) Cryptosporidium Source Tracking in the Potomac River Watershed. Applied and Environmental Microbiology, 74, 6495-6504. http://dx.doi.org/10.1128/AEM.01345-08

[22] Van Dyke, M.I., Ong, C.S.L., Prystajecky, N.A., Isaac-Renton, J.L. and Huck. P.M. (2012) Identifying Host Sources, Human Health Risk and Indicators of Cryptosporidium and Giardia in a Canadian Watershed Influenced by Urban and Rural Activities. Journal of Water and Health, 10, 311-323. http://dx.doi.org/10.2166/wh.2012.131

[23] Jiang, J., Alderisio, K.A. and Xiao, L. (2005) Distribution of Cryptosporidium Genotypes in Storm Event Water Samples from Three Watersheds in New York. Applied and Environmental Microbiology, 71, 4446-4454. http://dx.doi.org/10.1128/AEM.71.8.4446-4454.2005

[24] Keeley, A. and Faulkner, B.R. (2008) Influence of Land Use and Watershed Characteristics on Protozoa Contamination in a Potential Drinking Water Resources Reservoir. Water Research, 42, 2803-2813. http://dx.doi.org/10.1016/j.watres.2008.02.028

[25] Wilkes, G., Edge, T., Gannon, V., Jokinen, C., Lyautey, E., Medeiros, D., Neumann, N., Ruecker, N., Topp, E. and Lapen, D.R. (2009) Seasonal Relationships among Indicator Bacteria, Pathogenic Bacteria, Cryptosporidium oocysts, Giardia cysts, and Hydrological Indices for Surface Waters within an Agricultural Landscape. Water Research, 43, 2209-2223. http://dx.doi.org/10.1016/j.watres.2009.01.033

[26] Jellison, K., Distel, D., Hemond, H. and Schauer, D. (2007) Phylogenetic Analysis Implicates Birds as a Source of Cryptosporidium spp. oocysts in Agricultural Watersheds. Environmental Science and Technology, 41, 3620-3625. http://dx.doi.org/10.1021/es0626842

[27] Ruecker, N.J., Hoffman, R.M., Chalmers, R.M. and Neumann, N.F. (2011) Detection and Resolution of Cryptosporidium Species and Species Mixtures by Genus-Specific Nested PCR-Restriction Fragment Length Polymorphism Analysis, Direct Sequencing, and Cloning. Applied and Environmental Microbiology, 77, 3998-4007. http://dx.doi.org/10.1128/AEM.02706-10

[28] Craven, S.E., Stern, N.J., Line, E., Bailey, J.S., Cox, N.A. and Fedorka-Cray, P. (2000) Determination of the Incidence of Salmonella spp., Campylobacter jejuni, and Clostridium perfringens in Wild Birds near Broiler Chicken Houses by Sampling Intestinal Droppings. Avian Diseases, 44, 715-720. http://dx.doi.org/10.2307/1593118 